\title{
Using metaphor and narrative ideas in trauma and family therapy
}

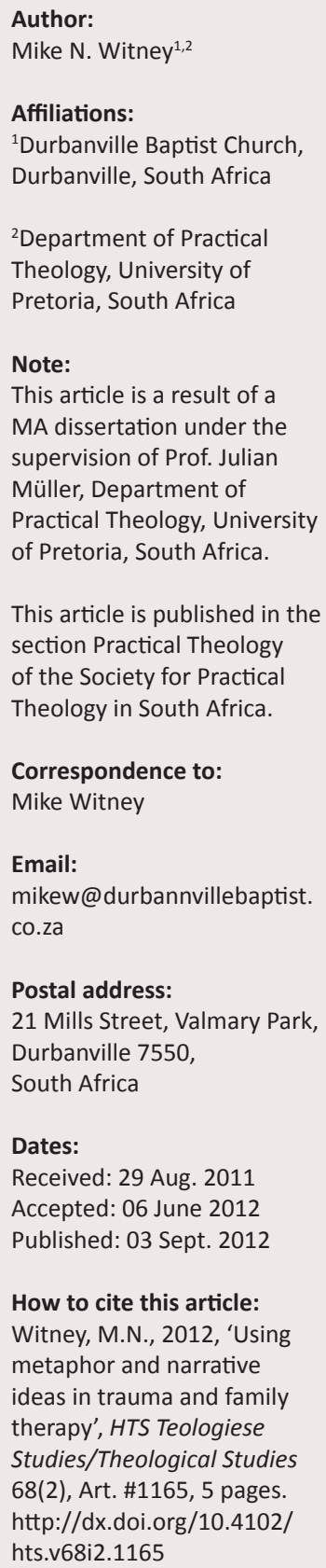

C 2012. The Authors.
Everyday people living in South Africa experience trauma, either first hand through accidents, crime, violence and abuse or through being witnesses to the traumatic event. This results in people in South Africa suffering from anxiety, depression, post-traumatic stress disorder (PTSD) and other severe mental health issues. One only has to read a newspaper, watch or listen to the news to get a glimpse of the landscape of trauma in our country. In this article I looked at using narrative ideas and metaphor in therapy with trauma and family therapy.

\section{Introduction}

After trauma, there:

is a retrospective alteration of the traumatic events meaning. This alteration of meaning is a defence mechanism that disrupts the memory of the event by means of repression or displacement of feelings. (Modell 2005)

With this as a backdrop, I would like to look at how we can use metaphor as a therapeutic vehicle, and narrative ideas in trauma and family therapy in the South African context.

When one reads the newspaper or watches the TV news, the one common denominator in the stories depicted is 'trauma'. Kaethe Weingarten calls this 'Common Shock' in her book of the same name (Weingarten 2003:4).

Yvonne Retief (2005) says the following in the foreword to her book Healing for Trauma in the South African context:

in South Africa with its high incidence of violent crime, divorce and other forms of trauma most people are emotionally wounded at one stage or another. If these wounds are not treated, they can leave severe scars and debilitate people, just like physical wounds do. (p. 22)

South Africa has the highest incidence of violence on women in the world (Ramphele 2008).

Four categories of abuse on women and children are defined as economic, emotional, physical and sexual with most occurring in the home (Rasool 2002).

According to South African Police Service (SAPS), every thirty seconds a child is raped and/ or sexually abused and more than 40000 cases of sexual abuse are handled in a year. Crimes statistics are a bit of a euphemism in South Africa, but according to SAPS statistics, there were 68332 cases of sexual offences reported in 2010 (SAPS 2010). Child abuse statistics, reported as neglect and ill-treatment of children in 2010 amounted to 4014 cases (SAPS 2010).

The following statistics demonstrate the level of trauma and violence against women in South Africa:

- at the time of death one out of two women in SA will be raped

- one out of three girls are raped or sexually assaulted before the age 18

- women in South Africa have a greater chance to be raped than to learn to read

- the threat of 'corrective' rape is very real for lesbian women in SA

- every six hours a woman is killed by her intimate partner, this is called Intimate Femicide (Spies 2012).

Violence in South Africa is seen in the following alarming statistics for 2010: murder 16834 cases, attempted murder 17410 cases; assault with intent to inflict bodily harm 205293 cases; common assault 197284 cases; kidnapping 2889 cases (SAPS 2010).

I believe that South Africans do not really have an idea of the magnitude of violence and trauma in our country, because it is only once the lid is taken off the secrecy of child abuse, incest, rape, sexual harassment or sexual victimisation, once the phenomenon of sexual victimisation 
is constructed and acknowledged as a problem, and once women are empowered to disclose and voice their secrets, the reality and the magnitude of the problem is revealed.

\section{Trauma in focus}

In the paper entitled 'The Lasting effects of Psychological trauma on memory' and the Hippocampus, trauma and abuse is seen as an invisible epidemic that represents a major health problem in society, because of the following alterations that take place in memory due to trauma and abuse: 'deficits in declarative memory [remembering facts or lists, as reviewed below], fragmentation of memories [both autobiographical and trauma-related] and dissociative amnesia [gaps in memory that can occur for minutes to days and are not due to ordinary forgetting]' (Bremner 1999:3).

Kaethe Weingarten (2003) explains that the fear experience during trauma:

can cause such high levels of stimulation in the amygdala that it blocks the hippocampus from working properly to evaluate and make meaning of the experience and in some cases people may 'dissociate' or 'space' out, which interferes with their ability to assimilate the intense sensory information they are experiencing with a meaningful personal narrative that makes sense or meaning of what is occurring. (p. 49)

In my research for my Master's dissertation I came to the following conclusions that resonate well with Bremner and Weingarten's ideas about the alteration of memory and meaning making as a result of trauma (Witney 2011).

As humans we are 'meaning seekers' (Marcu 2007:58-59) and from birth we continuously construct meaning in reaction to the interchange of feelings or emotions.

When we experience trauma, there is 'a retrospective alteration of these meanings. This alteration of meaning is a defence mechanism that disrupts the memory of the event by means of repression or displacement of feelings' (Modell 2005:3). Modell goes on to explain that metaphor functions as a pattern detector so that pre-trauma meanings are unconsciously transferred into the here and now.

Meaning making is central to our being and Frankl (1992:115) observed that the need for making meaning is a fundamental human motivational factor. Frankl goes on to say that he believes that the ability for people to survive after trauma is often dependent on their ability to derive meaning of the effects of the trauma.

Meaning making and our sense of objective reality are linked and reality can be understood by individuals as their lived experience, common sense and the knowledge of day to day habitual behaviours. When these are acted out in life, one gains a sense of objective reality. Our experiences are interpreted in terms of this objective reality and meaning making for the individual when they are perceived as making sense in terms of that objective reality.
Traumatic events and abuse that cannot be explained and are outside of the bounds of this reality tend to shatter these realities and their meaning making. In response to this 'shattered reality', individuals have to re-construct or re-author their reality in order to accommodate these new realties. These shattered paradigms and experiences are further complicated because in response to the trauma, as described above, the normal neural pathways are disrupted in the hippocampus so that meaning making is further complicated.

Crossley (2000:11) suggests that the sensory and perceptual faculties of human beings do not serve merely as conduits which enable an experience of the world, but also act interpretively to create meaning of events in terms of their interconnectedness.

He continues by saying that it is the connections or relationships among events that constitute their meanings and cultural meaning systems, such as language, provide the context for the creation of meaning' (2000:11).

I believe that metaphor, like the sports metaphor, which I will describe shortly, functions in this way, assisting our clients to create, find and make new meanings of their trauma as it 'acts like the currency of the mind' (Modell 2005:4).

I also maintain that this metaphor not only assists people to discover these connections, but also facilitates the finding and making of new meaning. It seems as if the metaphor helps put the 'shattered' puzzle pieces of meaning back together. The puzzle does, however, look different from what it looked like before it was shattered by the trauma. This 'difference' is the new meaning and agency that has been found and made, through the re-authoring that has taken place during the therapy using metaphor as a therapeutic vehicle.

\section{Team of life metaphor}

For the purpose of this article I would like to discuss a metaphor called 'Team of Life' metaphor that can be used as a therapeutic vehicle in trauma work. We will first look at the metaphor and then I will share a case study using that metaphor in therapeutic practice.

The 'Team of Life' metaphor was developed by David Denborough, from the Dulwich Centre in Australia. (Denborough 2008:1-126). The 'Team of Life' metaphor seeks to use the richness of meaning that can be found in the sporting culture and experience, to enable people who have experienced trauma to speak differently about their lives and seeks to allow people to give double-storied testimonies (Denborough 2006:115-131; White 2007:136-137) of their lives. These are testimonies that acknowledge hardship, but also show the richly nuanced way in which people and their loved ones respond to trauma (Denborough 2008:103). 
The 'Team of Life' methodology consists of five parts:

- what we like or love about the game

- creating our 'Team of Life'

- celebrating goals

- tackling problems

- avoiding obstacles and assisting others (Denborough 2008:104).

The 'Team of Life' methodology lends itself to group or individual work, which is advantageous in trauma work. I have personally only used this methodology in individual work, which leads me to Jane's story.

\section{Case study}

Jane, aged 12 years, came to therapy after she developed, what a school counsellor described, as separation anxiety. From an ethical and safety point of view, I had written permission from both parents to work with Jane, and her mother was present during all our sessions, again with Jane's approval. The anxiety manifested in many ways, her mother needed to walk with her to her class at school, and be waiting at the school gate when she finished school.

Any change in routine, a new teacher, a new sports coach, would cause Jane to experience stomach cramps, palpitations, shortness of breath and often tremendous feelings of fear and anxiety. Jane was also unable to sleep overnight at friends, or attend school or sport camps. This had a profound effect on Jane, because she missed out on so many outings and was often teased at school about being scared of camping.

I approached our therapy using narrative ideas and we externalised the feeling of cramps and anxiety which she named 'ouch'. When we spoke of 'ouch' and how 'ouch' affected her, she became distressed and found it difficult to express her emotions. I knew that she was a keen hockey player so we discussed using the 'Team of Life' metaphor, using hockey as the sport. We started our work by drawing the outlines of a hockey field on flip chart paper. Then Jane started choosing her team that would help her win the game against 'ouch'. It was interesting to see how connected she was to her faith base, as she placed God and the Holy Spirit in her goals, as goal keeper, along with her mother. Her father and her one brother were in her backline; as defence she used her best friends from school. On the opposing side she drew 'ouch' which looked like a peanut shell and then after some conversations, she drew smaller 'ouches' and named them as the issues that caused 'ouch' to visit. She named them, and prioritised them (1 high - 10 low) according to how much they contributed to the feelings of 'ouch'.

When I asked her, what her metaphor for the traumatic event that triggered 'ouch' was - the metaphor for the anxiety and cramps that she experienced - she said 'I don't talk about that' and immediately changed the subject. She placed her grandparents, an uncle and a favourite schoolteacher in her grandstands, to encourage her in the game. She called her team 'Team Shucks'. She drew a team emblem, wrote a team song and the team motto was to 'eliminate ouch'. Each week in therapy we would talk about the game, allow her to demonstrate tackles and she would use these tackles to score goals against 'ouch'.

During one session she said that the game was getting unfair for 'ouch' - which just demonstrated the agency she had found in the therapy - and expressed the hope that she would be able to stand up against 'ouch' and the effects of the trauma on her.

During another session we were able to externalise 'ouch' and she described 'ouch' as follows:

"'Ouch" is a feeling not a problem. He makes my stomach hurt, he makes me cry, he makes me feel scared and I get frustrated with him BUT he cannot control me, and can only stop me from doing some things, and with those things I am getting better. "Ouch" is getting smaller.' (Jane)

Again we see the agency she finds as we journey with 'ouch' using the metaphor of the game and 'ouch' as a peanut. Each week she took some unshelled peanuts home to remind her of the ways she could annihilate 'ouch' like: crush them, stand on them, eat them, throw them.

I would also send her a therapeutic letter after the session via email to encourage her and strengthen agency, as she reflected on the things we had spoken about in therapy.

During one session I asked her if we could start talking about 'thing', she said she would when she had more control of 'ouch'. She said that when we started working together she was maybe a 1 in 10 in control of 'ouch' now she is at a 6 - it needs to be at about an 8 before we can work on 'thing'.

We developed a team emblem for Team Shucks with the motto 'annihilate ouch' and the team mascot was 'Squiggles' her favourite fluffy toy.

After some school holidays she said that she was ready to talk about 'thing'. To allow her to feel safe and less stressed I suggested that she play with clay. I also explained the concept of subjective units of distress (SUD) scales with her (Wolpe 1969:100-122). She played with clay whilst we spoke, and she shared the traumatic story, without much increase in her SUD scales. She explained her meaning of the 'ouch' and how it influences her life:

"The "ouch", when she wanted to sleep over at a friend or on a camp, was linked to the traumatic event that she had witnessed and she became scared that something might happen to her parents if she was away from home. It was an interesting new meaning that she needed to make, she knew that this traumatic event would not happen again, but she found it difficult to thicken the alterative story and find a place of a new safe meaning. I also asked her mother to join her in thickening this alternative story, during the week between sessions.' (Jane)

At the next session we celebrated the progress she had made since we started our work in January:

'Getting into trouble gone, the lines issue gone, "the thing" got smaller, I scored major goals against "ouch", I have supporters, team mates and a safe place in my hockey game against "ouch".' (Jane) 
I gave her certificate for standing up against 'ouch' and agreed that her next big goal was to go on a hike with her scout group. She was able to do the hike, and stand up against 'ouch' so we celebrated it by having a milkshake at Wimpy.

We also discussed having a sleepover at a friend's house during the holidays, but she would have the fire escape of 'I can go home in the evening if ouch gets too much'. She was able to do the sleepover, and this was a turning point in her therapy, because the problem-saturated story of fear that 'ouch' had on her was now diminished. We continued to meet for top-up sessions and 'ouch' occasionally visits, especially when she is in strange or unfamiliar surroundings. She has been able to sleep over at friends for a few nights; she has gone on a camp and travelled overseas with her mother, without any major effects. The embodied physiological effects like the stomach cramps have not disappeared totally, but I believe that they too will subside with time.

\section{Reflection}

The narrative approach described in this case study showed the effectiveness of using narrative ideas and metaphor in trauma work. Through this therapeutic approach, we were able to eliminate 'ouch' (Jane's response to the traumatic event), we enabled Jane to stand up against many obstacles in life and share stories that make her stronger, without retraumatising her.

The time span of the therapy is also significant: we managed to get control over 'ouch' in a few months, where more traditional psychodynamic interventions had not been helpful. She had seen several other therapists over a period of two years - since the traumatic event - with little therapeutic value.

\section{Conclusion}

As I mentioned in my introduction, the incidence of trauma is very high in South Africa, most of our population has little or no access to trauma counselling and I believe in years to come we are going to see the alarming effects of this trauma on society.

I also believe that as ministers, pastoral therapists and psychologists we can offer trauma therapy to many more people by using 'narrative ideas and metaphor', because we can do the type of work outlined in this article in a group-

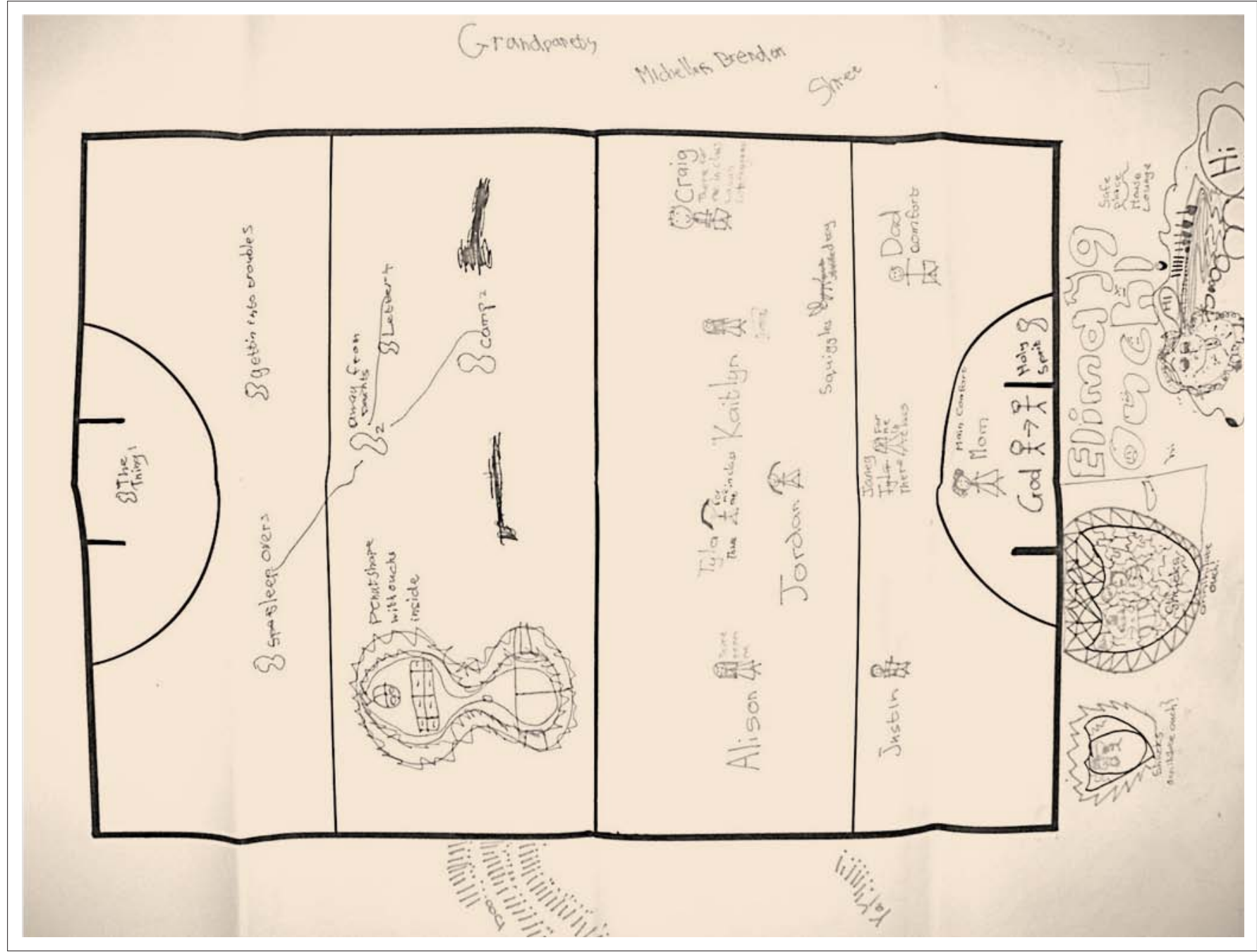

Source: Denborough, D., 2008, Collective Narrative Practices: Responding to individuals, groups, and communities who have experienced trauma, Dulwich Centre Publications, Adelaide. FIGURE 1: Team of Life Metaphor. 
therapy environment, thereby reaching more people. We can equip counsellors and therapists with the tools to do this work with minimal training, and the model can be used with little children as well as with adults. One needs minimal equipment, one could draw the sports metaphor in the sand at an informal settlement; one could use a few pieces of paper and crayons and be able to do the work. I think the only drawback I see, is that one needs to be open to new ideas of therapy and have some grasp of a few narrative ideas to be able to do the work effectively. I really believe that this alternative model for trauma therapy, using narrative ideas, could really impact trauma work in South Africa, because it is simple, there is no need for sophisticated equipment, therapists can be trained easily and racial, cultural and language barriers don't exist, for this therapeutic model.

\section{Acknowledgements}

\section{Competing interests}

The author declares that he has no financial or personal relationship(s) which may have inappropriately influenced him in writing this article.

\section{References}

Bremner, J., 1999, The lasting effects of Psychological trauma on memory and the Hippocampus, Department of Diagnostic Radiology and Psychiatry, Yale University Medical School, New Haven, CT.
Crossley, M., 2000, Introducing Narrative Psychology: Self trauma and the constrution of meaning, Open University Press, Buckingham.

Denborough, D., 2006, Trauma: Narrative Responses to traumatic experiences, Dulwich Centre Publications, Adelaide.

Denborough, D., 2008, Collective Narrative Practices: Responding to individuals, groups, and communities who have experienced trauma, Dulwich Centre Publications, Adelaide.

Frankl, V.E., 1992, Man's search for meaning, Beacon Press, Boston, MA.

Marcu, O., 2007, Meaning-making and coping: Making sense of death, Health Psychology Research Centre, Cluj-Napoca.

Modell, A.H., 2005, 'Emotional Memory, Metaphor, and Meaning', Psychoanalytic Inquiry 25, 555-568. http://dx.doi.org/10.2513/s07351690pi2504_9

Ramphele, M., 2008, Laying Ghosts to rest: Dilemmas of the transformation in South Africa, Paarl Print, Paarl.

Rasool, S.V., 2002, Violence against women: A National Survey, Institute for Security Studies, Pretoria.

Retief, Y., 2005, Healing for Trauma in the South African Context, Struik Christian Books, Cape Town.

South African Police Services (SAPS), 2010, 'Crime Statistics: April 2009-March 2010', SAPS, Pretoria.

Spies, N., 2012, South African women are in a war situation, viewed 12 May 2011, from http://www.facebook.com/l.php?u=http\%3A\%2F\%2Fnickispies. wordpress.com $\% 2$ F2012\%2F02\%2F04\%2Fsouth-africa-women-are-in-a-warwordpress.com $\% 2 F 2012 \% 2$
situation\%2F\&h=iAQESE8Lq

Weingarten, K., 2003, Common Shock: Witnessing Violence every day, Penguin Group, New York, NY.

White, M., 2007, Maps of Narrative Practice, W.W. Norton \& Company, New York, NY.

Witney M.N., 2011, 'The role of memory in finding and making meaning in and through grief', MA dissertation, Department of Theology, University of Pretoria, viewed November 2011, from $111022<$ http://upetd.up.ac.za/thesis/available/ etd-12022011-160308/

Wolpe, J., 1969, The Practice of Behavioral Therapy, Pergamon Press Ltd, New York, NY. 